\title{
Surface Water Quality in Aquacultural Areas in an Giang Province, Vietnam
}

\author{
Nguyen Thanh Giao
}

\author{
College of Environment and Natural Resources, Can Tho University, Vietnam \\ Corresponding Author: ntgiao@ctu.edu.vn
}

\begin{abstract}
This study was conducted to assess the impact of aquaculture with three fish cultivating models including net fence, cage and earth-pond to surface water quality, using water monitoring data from 2011 to 2019 provided by Department of Natural Resources and Environment, An Giang province, Vietnam. Water quality parameters included temperature, $\mathrm{pH}$, dissolved oxygen (DO), total suspended solids (TSS), biochemical oxygen demand (BOD), nitrate $\left(\mathrm{NO}_{3}{ }^{-} \mathrm{N}\right)$, orthophosphate $\left(\mathrm{PO}_{4}{ }^{3-} \mathrm{-}\right)$ and coliforms at 13 locations were evaluated followed the National Technical Regulation on surface water quality (QCVN 08MT: 2015/BTNMT). Multivariate analysis methods comprising Cluster Analysis (CA) and Principal Component Analysis (PCA) were used to group sampling locations according to pollution levels and to identify main water variables influencing on surface water quality. In the aquacultural areas, DO was low while TSS, BOD, $\mathrm{PO}_{4}{ }^{3-}-\mathrm{P}$ and coliform were high comparing to QCVN 08-MT: 2015/BTNMT. Among the three types of aquaculture, earth-pond culture resulted in more serious environmental pollution than cage and net fence. Five sources of pollution in the studied water bodies were identified using PCA in which temperature, $\mathrm{pH}, \mathrm{DO}, \mathrm{TSS}, \mathrm{BOD}, \mathrm{NO}_{3}{ }^{-} \mathrm{N}, \mathrm{PO}_{4}{ }^{3-}-\mathrm{P}$ and coliforms could reflect the quality of water environment affected by aquaculture. CA finding suggested that the number of monitoring points could be reduced from 13 to 9 sampling locations, thus reducing monitoring cost. Future studies should focus on investigating sources of surface water pollution in the aquacultural areas.
\end{abstract}

Keywords - surface water quality, net fence, earth-pond, cage, organic pollution, microorganisms, An Giang.

\section{INTRODUCTION}

An Giang is one of the localities highly potential for economic development in the Mekong Delta region. The dense rivers, canals and abundant fishery resources have generated favorable conditions for the province to increasingly develop its potential, especially its strengths in aquaculture. Approximate140 species of fish have been added during the annual flood season (Nhi, 2005). According to the Department of Agriculture and Rural Development of An Giang province, the area of aquaculture in 2013 reached 2,496 hectares, including the main cultured species of Tra catfish (Pangasius hypophthalmus), giant freshwater prawn (Macrobrachium rosenbergii), snakehead fish (Channa striata), basa (Pangasius bocourti), grouper (Pangasius conchophilus), he fish (Barbonymus altus), tilapia (Oreochromis niloticus). Of which, Pangasius hypophthalmus is the main fish for farming in the province with an area of 1,119 ha with a harvested fish output of 273,939 tons equal to $120 \%$ compared to 2018. In the first nine months of 2019, the socio-economic situation of the first nine months of 2019 reached 361,000 tons, increasing 4.6\% (+ 15.8 thousand tons) over the same period. Of which, cultivation were 347.6 thousand tons, increased 5.8\% (Pangasius hypophthalmus accounted for 287.6 thousand tons, increased 7.4\%); exploitation was 13.6 thousand tons, equaling $87.8 \%$ over the same period, due to low flood water this year reducing natural aquatic resources. Currently, most aquaculture areas do not have water treatment system and cleaning the wastewater maily relies on self-purification of water.

Aquaculture is often associated with environmental pollution if it is not well managed. One of the common environmental problems is the release of excess nutrients into the environment. Thich (2008) reported that the amount of $\mathrm{N}$ discharged from intensive Pangasius hypophthalmus ponds was $57.3 \%$ (5.43\% in water, $50.4 \%$ accumulated in sediment and $1.5 \%$ losses due to evaporation or infiltration) and the amount of $\mathrm{P}$ release was $70.2 \%$ (1.8\% in water, $64.5 \%$ in sediment and $3.9 \%$ losses 
due to evaporation or infiltration). Producing one ton of catfish would discharge $25.2 \mathrm{~kg} \mathrm{~N}$ and $12.6 \mathrm{~kg} \mathrm{P}$ into the environments. The results also showed that $48.0-87.3 \%$ of nitrogen $(\mathrm{N})$ and $75.0-94.0 \%$ of phosphorus $(\mathrm{P})$ of inputs in shrimp ponds were not absorbed for building up shrimp biomass but discharged into the environment through replacing water, discharging at harvest, depositing in pond bottom. It was calculated that every ton of shrimp would discharge approximate $16.8-157.2 \mathrm{~kg}$ of $\mathrm{N}$ and $2.3-45.9$ $\mathrm{kg}$ of $\mathrm{P}$ into the environment depending on the food source as well as intensive level.

Several chemicals were also used in Pangasius hypophthalmus farming. According to Phu et al. (2012) investigated chemical use in catfish farming in Chau Thanh district, Dong Thap showed that there were 28 chemicals used to improve water quality, for examples BKC, Zeolite, Chlorine, Formol, Attack, Protex, Vorkon), 8 types of chemicals were added to foods (such as Vitamin C, intestinal probiotics, Sorbitol, Premix types including Yucca, Levet, Zyme Biotic) and 14 antibiotics (such as Enrofloxacin, Sufadimethoxine, Trimethoprime). Le and Munekage (2004) reported Trimethoprim, Sulfamethoxazole, Norfloxacin and Oxolinic acid in the water samples were found at $1.04 ; 2.39 ; 6.06$ and 2.50 ppm, respectively and in the sediment samples at 734.61 ; 820,49; 2615.96; 426.31 ppm, respectively. Consequently, the antibiotics resulted in resistant strains of bacteria at most research sites. In addition to the impacts of aquaculture on surface water quality, natural activities such as erosion, stormwater runoff, production and business activities, residential and urban areas, industrial production activities also affect surface water quality (Nga, 2009; Ly and Giao, 2018; Truc, 2019).

Multivariate analysis methods including cluster analysis and principal component analysis are widely applied to assess water quality according to space and time at several monitoring locations using multiparameters (Zeinalzadeh and Rezaei, 2017). Multivariate analysis is used to assess changes in river water quality and identify sources of pollutants (Chounlamany et al., 2017). In addition, the multivariate analysis method is used to establish water monitor network and identify water quality variables that cause changes in surface water quality (Zeinalzadeh and Rezaei, 2017). This study was conducted to assess surface water quality in aquaculture areas in the form of net fence, cage and earth-pond between 2011 and 2019. The results of the study could provide scientific information on progression of water quality due to the impact of aquaculture for better management of water quality in aquacultural sector.

\section{MATERIALS AND METHODS}

\subsection{Water quality data}

The data on surface water quality in An Giang province was collected at the Department of Natural Resources and Environment of An Giang province in the period of 9 years from 2011 to 2019 at 13 locations in three types of aquacultural farming including three locations in the net fence model (TS7, TS8, TS9), three locations in the cage model (TS1, TS3, TS4) and seven locations in the earth-pond model (TS2, TS5, TS6, TS10, TS11, TS12, TS13). The sampling locations were shown in Figure 1. Water quality parameters including temperature, $\mathrm{pH}$ and dissolved oxygen (DO) were measured directly on site by handheld device. The water quality parameters such as biological oxygen demand (BOD), nitrogen nitrate $\left(\mathrm{NO}_{3}{ }^{-}-\right.$ $\mathrm{N})$, orthophosphate $\left(\mathrm{PO}_{4}{ }^{3-}-\mathrm{P}\right)$, and coliforms were collected, properly stored and transported to the laboratory for the analysis using standard methods listed in Table 1.

Table 1. Water quality parameters and analytical methods

\begin{tabular}{clcl}
\hline No. & \multicolumn{1}{c}{ Water parameters } & Unit & \multicolumn{1}{c}{ Analytical methods } \\
\hline $\mathbf{1}$ & Temperature & ${ }^{\circ} \mathrm{C}$ & SMEWW 2550B:2012 \\
\hline $\mathbf{2}$ & $\mathrm{pH}$ & - & TCVN 6492:2011 \\
\hline $\mathbf{3}$ & Dissolved oxygen (DO) & $\mathrm{mg} / \mathrm{L}$ & TCVN 7325:2004 \\
\hline $\mathbf{4}$ & Total suspended solids (TSS) & $\mathrm{mg} / \mathrm{L}$ & SMEWW 2540D:2012 \\
\hline $\mathbf{5}$ & Biological oxygen demand (BOD 5$)$ & $\mathrm{mg} / \mathrm{L}$ & SMEWW 5210B:2012 \\
\hline $\mathbf{6}$ & Nitrate $\left(\mathrm{NO}_{3}{ }^{-}\right.$as $\left.\mathrm{N}\right)$ & $\mathrm{mg} / \mathrm{L}$ & SMEWW 4500-NO ${ }^{-} \cdot \mathrm{E}: 2012$ \\
\hline $\mathbf{7}$ & Orthophosphate $\left(\mathrm{PO}_{4}{ }^{3-}\right.$ as $\left.\mathrm{P}\right)$ & $\mathrm{mg} / \mathrm{L}$ & SMEWW 4500-P.E:2012 \\
\hline $\mathbf{8}$ & Coliforms & $\mathrm{MPN} / 100 \mathrm{~mL}$ & TCVN 6187-2:1996 \\
\hline
\end{tabular}




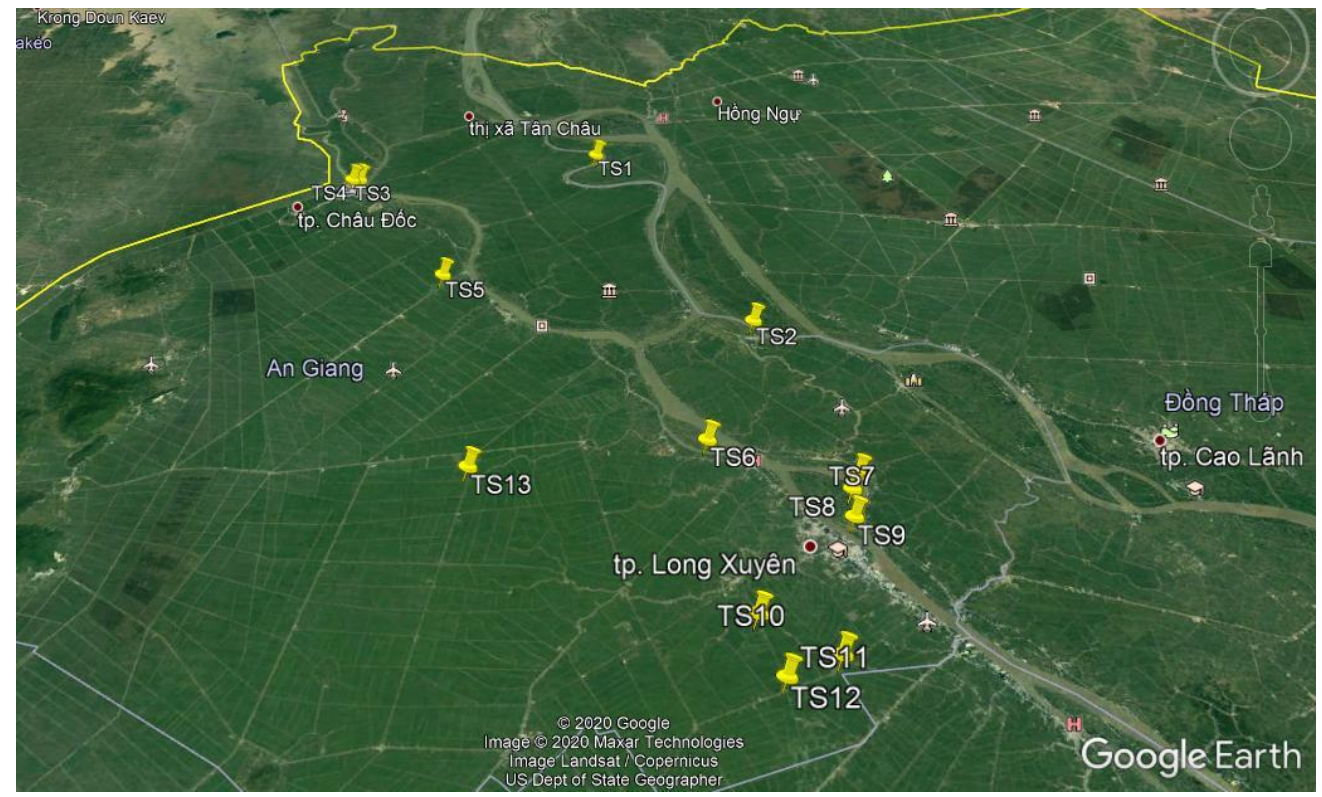

Fig.1: Locations of water quality samples (Google Earth, 2020)

\subsection{Data processing}

The difference in the mean value of the water quality parameters was performed by analysis of variance (ANOVA), at the significance level of 5\%, Duncan test (Ahrari et al., 2015) using statistical software IBM SPSS statistics for Windows, Version 20.0 (IBM Corp., Armonk, NY, USA). The two main methods used in the evaluation of monitoring data are Cluster Analysis (CA) and Principal Component Analysis (PCA). The cluster analysis method is applied to group water locations based on all physical, chemical and biological criteria. Sampling sites with similar pollution characteristics will be grouped into the same group, while different pollution characteristics will be grouped into another group and presented as a structural tree (Feher et al., 2016; Chounlamany et al., 2017). PCA method is used to reduce initial data variables that do not make an important contribution to data fluctuation while creating a new group of variables called principal components (PC). These PCs are not related to each other and appear in descending order of importance. The important value to consider in principal component analysis is the eigenvalue coefficient, the greater the coefficient, the greater the major contribution to explaining the variability of the original dataset. This technique is used to determine the number of sources that affect surface water quality in environmental monitoring (Feher et al., 2016). The correlation between the principal component and the primary data variables (water quality indicators) is shown by the significant correlation coefficients (Feher et al., 2016). The absolute value of the significant correlation coefficient is greater than 0.75 , which means that the strong correlation between the principal components and water quality criteria, from $0.75-0.5$ is the average correlation, and 0.5-0.3 is the weak correlation (Liu et al., 2003). CA and PCA are implemented using copyrighted Primer Software V5.2.9 (Plymounth, UK).

\section{RESULTS AND DISCUSSION}

\subsection{Water quality in the fish cultivating areas}

The surface water quality affected by cultivating models were presented in Tables 2-4. Water temperature at 13 sampling locations in three models were in the range of $29.8 \pm 1.3-29.9 \pm 1.0^{\circ} \mathrm{C}, \quad 29.4 \pm 0.7-29.6 \pm 1.0^{\circ} \mathrm{C}, \quad 29.0 \pm 0.7-$ $30.3 \pm 1.1^{\circ} \mathrm{C}$ in the cage, net fence and earth-pond models, respectively in the period of nine years. Previous study showed that temperature in Hau River ranged from 27.1$32.0^{\circ} \mathrm{C}$ (Giao, 2020) and Mekong River ranged from 19.9 to $32.2^{\circ} \mathrm{C}$ (Ongley, 2009). Water temperature at the study sites is still suitable for aquatic life according to National technical regulation on surface water quality (QCVN 08MT: 2015/BTNMT) and Boyd (1998). The mean pH values in the two areas influenced by cage model (7.1 \pm 0.2 $7.2 \pm 0.2)$ and net fence $(7.0 \pm 0.2-7.2 \pm 0.3)$ were not much different over the years as well as the sampling locations, fluctuating around the neutral value. In the earth-pond area, the mean $\mathrm{pH}$ ranged from $6.7 \pm 0.3$ to $7 \pm 0.3$ which is slightly lower compared to the other models. Previous studies reported the $\mathrm{pH}$ values in Tien river and Hau river ranged from 7.1 to $7.2,6.7$ to 7.12 (Giao, 2020). The $\mathrm{pH}$ values were still suitable for the development of fish as well as aquatic animals and plants (QCVN 08-MT: 
2015/BTNMT, column A1). The mean DO concentrations in the cage, net fence and earth-pond models were in the ranges of $4.8 \pm 1.0-4.9 \pm 1.0, \quad 5.2 \pm 1.0-5.5 \pm 0.9, \quad 3.9 \pm 0.7-$ $5.5 \pm 1.0 \mathrm{mg} / \mathrm{L}$, respectively (Table 2-4). There was high variation of DO in the earth-pond area compared to the cage and net fence models. However, DO at the water bodies influenced by fish cultivating areas were lower compared to QCVN 08-MT: 2015/BTNMT which could indicate influence of fish cultivation on surface water quality. Previous studies presented that DO in the rivers rarely meet the national standard. For example, DO concentration in Hau river were in the ranges of $4.8 \pm 1.1$ $5.5 \pm 0.7 \mathrm{mg} \mathrm{L}^{-1}$ (Lien et al., 2016), and $5.29 \pm 0.33-5.65$ $\pm 0.56 \mathrm{mg} \mathrm{L}^{-1}$ (Giao, 2020). DO in canals in Soc Trang province ranged from 1.7 to $6.17 \mathrm{mg} \mathrm{L}^{-1}$ (Tuan et al., 2019). The release of wastewater containing nutrients and organic matters could be the main cause of low DO concentration in the aquacultural areas (Ngoc, 2004; Te and Munekage, 2004; Thich, 2008). According to Ongley (2009), the DO concentration suitable for aquatic life is at least $5 \mathrm{mg} / \mathrm{L}$ or higher, but the DO concentration at the study sites were relatively low, showing that the water source has been organically polluted. Measures are urgently needed for better management of the surface water quality influenced by aquacultural activities.

Table 2. Surface water quality affected by cage cultivating model

\begin{tabular}{llllc}
\hline Variables & TS1 & TS3 & TS4 & *QCVN \\
\hline Temp. & $29.9 \pm 1.0$ & $29.9 \pm 1.3$ & $29.8 \pm 1.3$ & - \\
\hline pH & $7.2 \pm 0.2$ & $7.1 \pm 0.2$ & $7.1 \pm 0.2$ & $6-8.5$ \\
\hline DO & $4.8 \pm 1.0$ & $4.9 \pm 1.0$ & $4.9 \pm 1.0$ & $\geq 6 \mathrm{mg} / \mathrm{L}$ \\
\hline TSS & $43.2 \pm 18.8$ & $36.1 \pm 13.9$ & $36.8 \pm 15.8$ & $20 \mathrm{mg} / \mathrm{L}$ \\
\hline BOD & $6.7 \pm 1.5$ & $7.6 \pm 2.5$ & $6.7 \pm 2.2$ & $4 \mathrm{mg} / \mathrm{L}$ \\
\hline NO3 $^{-}$-N & $0.3 \pm 0.2$ & $0.2 \pm 0.2$ & $0.2 \pm 0.2$ & $2 \mathrm{mg} / \mathrm{L}$ \\
\hline PO $^{3-}{ }^{-\mathbf{P}}$ & $0.1 \pm 0.1$ & $0.2 \pm 0.2$ & $0.1 \pm 0.1$ & $0.1 \mathrm{mg} / \mathrm{L}$ \\
\hline Coliforms $^{-3.9 \pm 0.5}$ & $3.5 \pm 0.4$ & $3.7 \pm 0.6$ & $3.339 \mathrm{MPN} / 100 \mathrm{~mL}$
\end{tabular}

Table 3. Surface water quality affected by net fence cultivating model

\begin{tabular}{llllc}
\hline Variables & TS7 & TS8 & TS9 & *QCVN \\
\hline Temp. & $29.5 \pm 0.9$ & $29.4 \pm 0.7$ & $29.6 \pm 1.0$ & - \\
\hline pH & $7.0 \pm 0.3$ & $7.0 \pm 0.2$ & $7.2 \pm 0.3$ & $6-8.5$ \\
\hline DO & $5.2 \pm 1.0$ & $5.3 \pm 0.9$ & $5.5 \pm 0.9$ & $\geq 6 \mathrm{mg} / \mathrm{L}$ \\
\hline TSS & $37.4 \pm 12.3$ & $44.6 \pm 16.8$ & $34.8 \pm 10.6$ & $20 \mathrm{mg} / \mathrm{L}$ \\
\hline BOD & $8.5 \pm 3.1$ & $10.7 \pm 6.6$ & $7.3 \pm 3.8$ & $4 \mathrm{mg} / \mathrm{L}$ \\
\hline NO $^{-}{ }^{-}-\mathbf{r}$ & $0.3 \pm 0.3$ & $0.4 \pm 0.3$ & $0.4 \pm 0.2$ & $2 \mathrm{mg} / \mathrm{L}$ \\
\hline PO $^{3-}{ }^{-P}$ & $0.3 \pm 0.3$ & $0.2 \pm 0.2$ & $0.1 \pm 0.0$ & $0.1 \mathrm{mg} / \mathrm{L}$ \\
\hline Coliforms $^{-3.5 \pm 0.6}$ & $3.6 \pm 0.5$ & $3.4 \pm 0.5$ & $3.339 \mathrm{MPN} / 100 \mathrm{~mL}$ \\
\hline
\end{tabular}

Table 4. Surface water quality affected by earth-pond cultivating model

\begin{tabular}{lllllllll}
\hline $\begin{array}{c}\text { Variabl } \\
\text { es }\end{array}$ & TS2 & TS5 & TS6 & TS10 & TS11 & TS12 & TS13 & *QCVN \\
\hline Temp. & $29.8 \pm 1.1$ & $29.5 \pm 1.6$ & $30.3 \pm 1.1$ & $29.6 \pm 1$ & $29.2 \pm 0.9$ & $29 \pm 0.7$ & $30 \pm 1.1$ & - \\
\hline pH & $6.9 \pm 0.2$ & $6.7 \pm 0.3$ & $6.9 \pm 0.2$ & $7.0 \pm 0.3$ & $6.9 \pm 0.2$ & $6.8 \pm 0.4$ & $6.8 \pm 0.2$ & $6-8.5$ \\
\hline DO & $5.5 \pm 1.0$ & $4.1 \pm 0.9$ & $4.9 \pm 0.6$ & $3.9 \pm 0.7$ & $3.9 \pm 0.9$ & $4.0 \pm 1.1$ & $3.9 \pm 0.7$ & $\geq 6 \mathrm{mg} / \mathrm{L}$ \\
\hline
\end{tabular}


International Journal of Environment, Agriculture and Biotechnology, 5(4)

Jul-Aug, 2020 / Available: https://ijeab.com/

\begin{tabular}{llllllllc}
\hline TSS & $50.0 \pm 24.1$ & $83.1 \pm 43$. & $49.3 \pm 24.2$ & $60.3 \pm 27.5$ & $64.8 \pm 17.0$ & $65.2 \pm 28.6$ & $78.7 \pm 21.1$ & $20 \mathrm{mg} / \mathrm{L}$ \\
& & 6 & & & & & & \\
\hline BOD & $10.9 \pm 7.6$ & $21.5 \pm 12$ & $7.5 \pm 2.6$ & $9.1 \pm 2.3$ & $9.3 \pm 4.0$ & $10.9 \pm 3.3$ & $12.8 \pm 5.8$ & $4 \mathrm{mg} / \mathrm{L}$ \\
\hline NO$^{-}{ }^{-}-\mathbf{N}$ & $0.36 \pm 0.28$ & $0.32 \pm 0.2$ & $0.4 \pm 0.36$ & $0.38 \pm 0.2$ & $0.40 \pm 0.3$ & $0.46 \pm 0.41$ & $0.35 \pm 0.2$ & $2 \mathrm{mg} / \mathrm{L}$ \\
& & 7 & & & & & & \\
\hline PO4 $^{{ }^{3-}-\mathbf{P}}$ & $0.21 \pm 0.17$ & $1.68 \pm 1.0$ & $0.23 \pm 0.12$ & $0.23 \pm 0.1$ & $0.32 \pm 0.2$ & $0.38 \pm 0.11$ & $0.43 \pm 0.46$ & $0.1 \mathrm{mg} / \mathrm{L}$ \\
\hline $\begin{array}{l}\text { Colifor } \\
\text { ms }\end{array}$ & $3.71 \pm 0.63$ & $4.11 \pm 0.4$ & $3.67 \pm 0.61$ & $3.91 \pm 0.6$ & $3.72 \pm 0.6$ & $3.72 \pm 0.56$ & $3.87 \pm 0.53$ & 3.339 \\
\hline
\end{tabular}

Note: * QCVN is the national technical regulation on surface water quality QCVN 08-MT: 2015/BTNMT, column Al which is used for domestic water supply, conservation of aquatic plants and animals; coliform was presented in log form.

The mean concentrations of TSS in the water bodies influenced by fish raising in cage, net fence and earth-pond models ranged from 36.1 $1313.9-43.2 \pm 18.8$ $\mathrm{mg} / \mathrm{L}$, from $34.8 \pm 10.6$ to $44.6 \pm 16.8 \mathrm{mg} / \mathrm{L}$, from $49.3 \pm 24.2$ to $83.1 \pm 43.6 \mathrm{mg} / \mathrm{L}$, respectively (Table 2-4). The fluctuation of the total suspended solids was relatively high through each sampling position in the period of 2011 2019. TSS tended to increase gradually over time, exceeding the permissible limit of QCVN 08-MT: 2015/BTNMT, column A. In the type of cage model, the highest TSS concentration was found in 2017 at the position of TS1 (Phu Tan) and the position of TS3 (Chau Doc) were accordingly $61.7 \pm 35.0$ and $66.7 \pm 18.4 \mathrm{mg} / \mathrm{L}$, exceeded QCVN 08-MT: 2015/BTNMT column A by 2.06 and 2.22 times, respectively. In the net fence cultivation model, the highest TSS concentration was found in 2017 in Long Xuyen City at the positions TS7 and TS8 with the values of TSS $63.7 \pm 7.6$ and $69.7 \pm 13.7 \mathrm{mg} / \mathrm{L}$, respectively exceeded QCVN 08-MT: 2015/BTNMT column A by 3.15 and 3.20 times. In the earth-pond cultivation areas, the highest TSS concentration was in 2014 at the TS5 site (Chau Phu) reaching $187 \pm 105.8$ $\mathrm{mg} / \mathrm{L}, 9.35$ times higher compared to QCVN 08-MT: 2015/BTNMT column A. Former studies reported that water bodies in the Vietnamese Mekong delta have been long contaminated by total suspended solids. For instances, TSS concentrations in Hau River ranged from $41.2 \pm 33.7$ to $89.57 \pm 31.31 \mathrm{mg} / \mathrm{L}$ (Lien et al., 2016), TSS in the canals in An Giang province in the period of 2009-2016 fluctuated from $25.0 \pm 11.5$ to $93.7 \pm 28.3 \mathrm{mg} / \mathrm{L}$ (Ly and Giao, 2018). In Soc Trang province, TSS concentrations in canals ranged from 16 to $176 \mathrm{mg} / \mathrm{L}$ (Tuan et al., 2019). In the current study, the average TSS concentrations in the earth-pond areas were more polluted than those at the cage and net fence areas. The findings revealed that aquacultural activities partly contributed to high TSS in the water bodies which could be artributed to the direct discharge or improperly treated of wastewater generated from aquacultural sites to the receiving waters.

The mean BOD concentrations were in the ranges of $6.7 \pm 1.5-7.6 \pm 2.5 \mathrm{mg} / \mathrm{L}, 7.3 \pm 3.8-10.7 \pm 6.6 \mathrm{mg} / \mathrm{L}$, and $7.5 \pm 2.6-21.5 \pm 12.0 \mathrm{mg} / \mathrm{L}$ in the cage, net fence and earthponds models, respectively (Table 2-4). BOD at the water bodies influenced by earth-pond cultural practices was found higher than those in the water bodies influenced by cage and net fence models. Previous studies reported that BOD concentration in water bodies in An Giang province was in the range of $6.6 \pm 1.2-8.2 \pm 2.5 \mathrm{mg} / \mathrm{L}$ ( Ly and Giao, 2018) which was lower than the values of BOD in the current study areas influenced by aquacultural activities. The mean BOD concentrations in the water bodies influenced by aquaculture exceeded QCVN 08-MT: 2015/BTNMT column A2, from 1.25 to 3.56 times. This result is consistent with the values of low DO and high TSS discussed in the previous sections.

$\mathrm{NO}_{3}{ }^{-}-\mathrm{N}$ concentrations in the cage, net fence and earth-pond models were in the ranges of $0.20 \pm 0.20$ $0.30 \pm 0.20,0.30 \pm 0.300 .40 \pm 0.30$, and $0.32 \pm 0.27-0.46 \pm 0.41$ $\mathrm{mg} / \mathrm{L}$, respectively. The data indicated that $\mathrm{NO}_{3}{ }^{-}-\mathrm{N}$ concentrations were highly fluctuated over the period of 2011-2019. The concentrations of $\mathrm{NO}_{3}{ }^{-}-\mathrm{N}$ in the water bodies in the the earth-pond model was higher than those influenced by cage and net fence models revealed the significant impact of the earth-pond model to surface water quality. Former studies reported that $\mathrm{NO}_{3}{ }^{-}-\mathrm{N}$ concentration in Hau River ranged from 0.002 to $0.395 \mathrm{mg} / \mathrm{L}$ (Lien et al., 2016), in river systems in Soc Trang province from 0.05 to $0.14 \mathrm{mg} / \mathrm{L}$ (Tuan et al., 2019). The concentration of nitrate in the current study was still in accordance with the permitted standard of QCVN 08-MT: 2015/BTNMT, column A1 (2 mg/L). According to Phu and Ut (2006), $\mathrm{NO}_{3}{ }^{-}-\mathrm{N}$ concentration suitable for aquatic species ranges from 0.1 to $10 \mathrm{mg} / \mathrm{L}$, so $\mathrm{NO}_{3}{ }^{-}-\mathrm{N}$ concentrations at all 
sampling points over nine years in the current study were in the suitable ranges for aquatic life. However, high concentrations of $\mathrm{NO}_{3}{ }^{-}-\mathrm{N}$ can potentially cause eutrophication which subsequently lead to degrade surface water quality resulting in unfavorable conditions for aquatic organisms.

Orthophosphate $\left(\mathrm{PO}_{4}{ }^{3-}-\mathrm{P}\right)$ concentrations ranged from $0.1 \pm 0.1$ to $0.2 \pm 0.2 \mathrm{mg} / \mathrm{L}, 0.1 \pm 0.0$ to $0.3 \pm 0.3 \mathrm{mg} / \mathrm{L}$, and $0.21 \pm 0.17$ to $1.68 \pm 1.01 \mathrm{mg} / \mathrm{L}$ at the water bodies influenced by cage, net fence and earth-pond models, respectively (Table 2-4). Concentrations of $\mathrm{PO}_{4}{ }^{3-}-\mathrm{P}$ in the water bodies influenced by the earth-pond model was much higher compared to those influenced by cage and net fence models. $\mathrm{PO}_{4}{ }^{3-}-\mathrm{P}$ agricultural areas and in Hau River ranged from 0.02 to $0.47 \mathrm{mg} / \mathrm{L}$ (Ly and Giao, 2018), in Hau River section from An Giang to Hau Giang provinces ranged from 0.04 to $0.11 \mathrm{mg} / \mathrm{L}$ (Giao, 2020), and in canals in Soc Trang province ranged from 0.05 to $0.9 \mathrm{mg} / \mathrm{L}$ (Tuan et al., 2019). The former studies and the current study revealed that $\mathrm{PO}_{4}{ }^{3-}-\mathrm{P}$ at the water bodies in the Vietnamese Mekong delta exceeded the QCVN 08-MT: 2015/BTNMT, column A1. The eutrophication is very likely to take place onece the $\mathrm{PO}_{4}{ }^{3-}-\mathrm{P}$ concentration is greater than $0.1 \mathrm{mg} / \mathrm{L}$ (Boyd and Green, 2002). This study found that surface water quality influenced by the aquacultural activities is at risk of eutrophication due to orthophosphate concentration.

The density of coliforms ranged from $3.5 \pm 0.4$ to $3.9 \pm 0.5$, from $3.4 \pm 0.5$ to $3.6 \pm 0.5$, and from $3.67 \pm 0.61$ to $4.11 \pm 0.47 \mathrm{MPN} / 100 \mathrm{~mL}$ at the water bodies influenced by cage, net fence and earth-pond models, respectively (Table 2-4) which exceeded QCVN 08-MT: 2015/BTNMT, column A1. The density of coliforms in the water bodies influenced by earth-pond culture was higher than those at the water bodies influenced by cage and net fence cultures. The results from this study was in accordance with the previous studies that the surface water in the Mekong delta of Vietnam have been long contaminated by coliforms (Lien at al., 2016, Ly and Giao, 2018, Tuan et al., 2019, Giao, 2020).

\subsection{Key parameters influencing water quality at the fishery cultivating areas}

A total of eight variables of water environment parameters were included in the PCA. The key water parameters influence on surface water quality were presented in Table 5. PC1 explained $58.4 \%$ of the variation in the data obtained. The source of this pollution is mainly reflected in the $\mathrm{pH}(0.420)$, TSS (-0.446), and BOD ($0.400)$. PC1 could explain for the water quality at the study site being polluted organically due to the residues of aquatic feed and untreated sewage in the areas of earthponds discharged directly into the receiving water. PC2 explained $18.7 \%$ of the fluctuation of water quality through temperature (0.50) and $\mathrm{NO}_{3}{ }^{-}-\mathrm{N}(-0.673)$. PC3 explained $11 \%$ of the data fluctuation, is affected by a moderate level of temperature (0.549), a weak level of DO (-0.445), and a $\mathrm{PO}_{4}{ }^{3-}-\mathrm{P}(-0,424)$. PC4 explained $7.4 \%$ of the data fluctuation, is affected by moderate level of temperature (0.575), DO (0.534) and weak level of $\mathrm{NO}_{3}{ }^{-} \mathrm{N}(0.441)$. PC5 explained only $2.3 \%$ of the water quality variation, affected by the weak level of DO (0.464) and the high level of coliforms (0.772), and showed that microbiological pollution at the surveyed locations. The results also showed that the change of temperature is influenced by at least three factors (PC2, PC3, and PC4), DO by three factors (PC3, PC4, and PC5) and $\mathrm{NO}_{3}^{-}-\mathrm{N}$ by two factors (PC2, PC4). The other indicators were only influenced by one PC. Thus, there are at least five sources of pollution affecting water quality in the water bodies that receive aquaculture wastewater. Water pollution sources could be hydrological regimes (currents, tides, and flows), erosion, aquaculture waste, and domestic waste. Eight monitoring indicators including temperature, $\mathrm{pH}$, DO, TSS, BOD, $\mathrm{NO}_{3}{ }^{-}-\mathrm{N}, \mathrm{PO}_{4}{ }^{3-}-\mathrm{P}$ and coliforms are all very important for monitoring water quality in the water bodies receiving aquacultural wastewater.

Table 5. The main parameters affecting surface water quality in aquaculture area

\begin{tabular}{lccccc}
\hline Parameters & PC1 & PC2 & PC3 & PC4 & PC5 \\
\hline Temp. & 0.173 & $\mathbf{0 . 5 0 9}$ & $\mathbf{0 . 5 4 9}$ & $\mathbf{0 . 5 7 5}$ & -0.228 \\
pH & $\mathbf{0 . 4 2 0}$ & 0.188 & -0.064 & -0.309 & -0.113 \\
TSS & $\mathbf{- 0 . 4 4 6}$ & 0.007 & 0.201 & 0.062 & -0.227 \\
DO & 0.356 & 0.095 & $\mathbf{- 0 . 4 5 4}$ & $\mathbf{0 . 5 3 4}$ & $\mathbf{0 . 4 6 4}$ \\
BOD & $\mathbf{- 0 . 4 0 0}$ & 0.214 & -0.398 & 0.218 & -0.097 \\
NO $^{-}{ }^{-\mathbf{N}}$ & -0.180 & $\mathbf{- 0 . 6 7 3}$ & 0.163 & $\mathbf{0 . 4 4 1}$ & 0.109 \\
$\mathbf{P O}_{4}{ }^{--}-\mathbf{P}$ & -0.375 & 0.297 & $\mathbf{- 0 . 4 2 4}$ & 0.089 & -0.225
\end{tabular}




\begin{tabular}{lccccc} 
Coliform & -0.367 & 0.332 & 0.287 & -0.186 & $\mathbf{0 . 7 7 2}$ \\
\hline Eigenvalue & 4.67 & 1.50 & 0.88 & 0.59 & 0.18 \\
Variation (\%) & 58.4 & 18.7 & 11.0 & 7.4 & 2.3 \\
Cum.Var (\%) & 58.4 & 77.1 & 88.1 & 95.6 & 97.8 \\
\hline
\end{tabular}

\subsection{Grouping water quality in the aquaculture area}

The results of water quality clustering were presented in Figure 2. At the distance of 4.0, water quality in the water bodies receiving aquaculture water can be classified into three groups. Group 1 includes the site TS5; Group 2 includes the locations of TS1, TS2, TS3, TS4, TS6, TS7, TS8, TS9; and Group 3 with the positions of TS10, TS11, TS12 and TS13. From this result, it is possible to select a water sampling location based on the locations in the same group with similar water quality, so only a representative location is needed. However, in this case, due to the locations in different water bodies such as Tien River (TS1, TS2), Chau Doc River (TS3), Hau River
(TS4, TS6, TS7, TS8, TS9), Xang Vinh Tre canal (TS5), Xa Doi Canal (TS10), Don Dong canal (TS11, TS12) and Tra Cu Canal (TS13), so the locations should be arranged according to the same rivers. On Tien River, it is possible to choose TS1 or TS2 because these two locations are grouped into Group 2; On the Hau River, only one sample from TS7-TS9 is required to be sampled and one of the three positions from TS7-TS9 is located in the same subgroup in Group 2. The two positions on the Don Dong channel are in the same group with Group 3, so only one is needed. Thus, from 13 sampling points can be reduced to 9 sampling points according to this study.

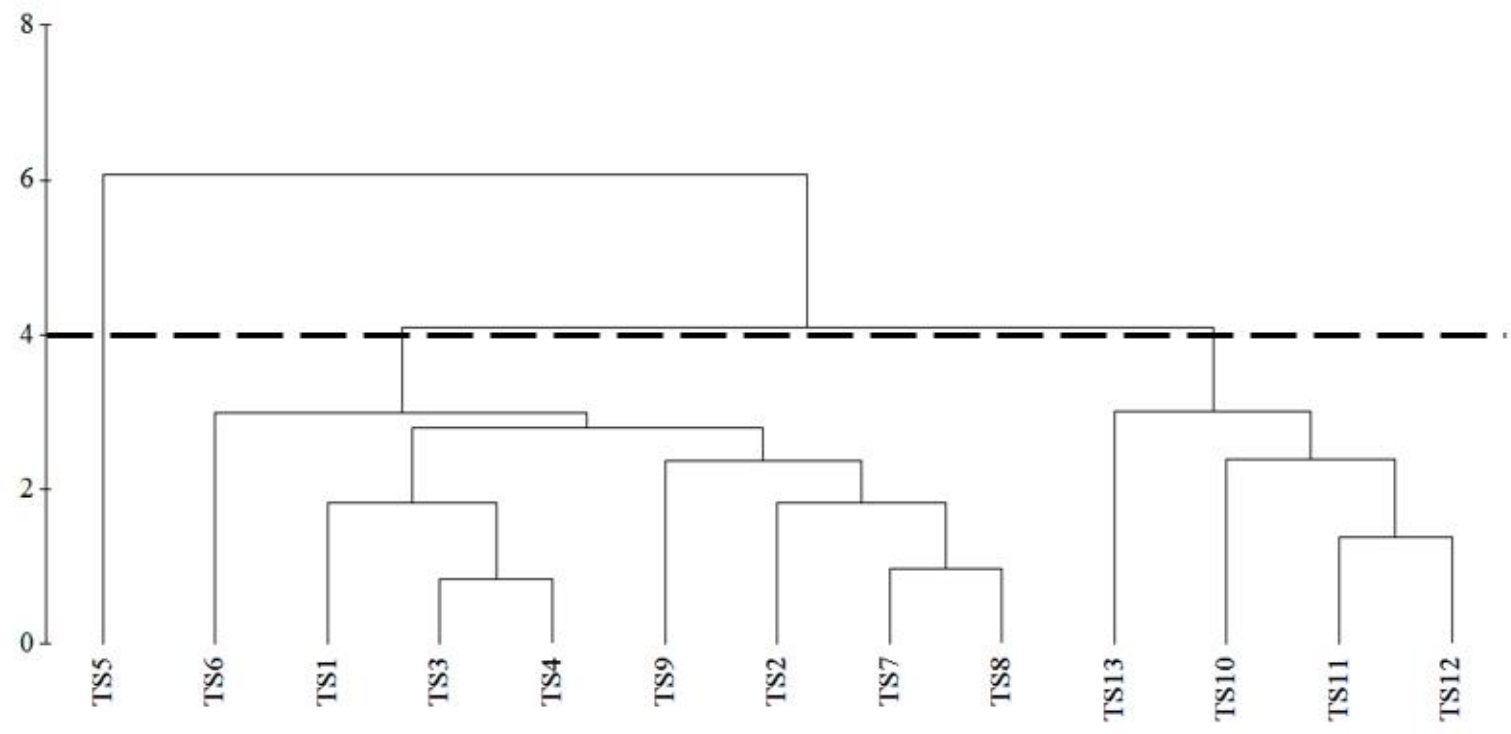

Fig.2: Grouping water quality using cluster analysis

\section{CONCLUSION}

The analysis of surface water quality affected by aquaculture activities in An Giang province in the period of 2011 - 2019 showed that the water has the problems of total suspended solids, organic matters and coliforms. Among the three types of aquaculture, earth-pond culture resulted in more serious environmental pollution than cage and net fence since the water quality assessment criteria such as DO, TSS, BOD, $\mathrm{NO}_{3}{ }^{-}-\mathrm{N}, \mathrm{PO}_{4}{ }^{3-}-\mathrm{P}$ and coliforms in earth-pond culture area were much higher than those at the cage and net fence areas. PCA analysis showed that there are five main factors corresponding to five sources of pollution in the studied water bodies. The parameters of temperature, $\mathrm{pH}, \mathrm{DO}, \mathrm{TSS}, \mathrm{BOD}, \mathrm{NO}_{3}{ }^{-}-\mathrm{N}, \mathrm{PO}_{4}{ }^{3-}-\mathrm{P}$ and coliforms are very important for monitoring water quality in the area receiving aquaculture wastewater. CA analysis showed that water quality in aquaculture-affected water bodies can be classified into three groups and from this grouping, the number of monitoring points can be reduced from 13 to 9 sampling points taking into account the different water bodies. Future study should focus on 
investigating specific sources of pollution to effectively solve the pollution problem in the study area.

\section{REFERENCES}

[1] Ahrari, F., Eslami, N., Rajabi, O., Ghazvini, K., Barati, S. (2015). The antimicrobial sensitivity of Streptococcus mutans and Streptococcus sangius to colloidal solutions of different nanoparticles applied as mouthwashes. Dental Research Journal 12:44-49.

[2] Boyd, C.E. (1998). Water quality for pond aquaculture. Resarch and development series. No.43. International center for aquaculture and aquatic environtments Alabama quaculture experient station Auburn University.

[3] Boyd, C.E., Green, B.W. (2002). Water quality monitoring in shrimp farming areas: an example from Honduras, Shrimp Farming and the Environment. Report prepared under the World Bank, NACA, WWF and FAO Consortium Program on Shrimp Farming and the Environment, Auburn, USA, pp. 29.

[4] Chounlamany, V., Tachuling, M.A. and Inoue, T. (2017). Spatial and temporal variation of water quality of a segment of Marikina River using multivariate statistical analyses, Water Science \& Technology 76, 1510-1522.

[5] Feher, I,C., Zaharie, M., Oprean, I. (2016). Spatial and seasonal variation of organic pollutants in surface water using multivariate statistical techniques. Water Science and Technology, 74: 1726-1735.

[6] Giao, N.T. (2020). Evaluating current water quality monitoring system on Hau River, Mekong delta, Vietnam using multivariate statistical technique. Journal of Applied Environmental Research, 42(1):14-25.

[7] Le, T.X., and Munekage, Y. (2004). Residues of selected antibiotics in water and mud from shrimp ponds in mangrove areas in Vietnam. Mar. Pollut. Bull. 49: 922-929.

[8] Lien, N.T.K., Huy, L.Q,. Oanh, D.T.H., Phu, T.Q., and Ut, V.N. (2016) Water quality in mainstream and tributaries of Hau River. Can Tho University Journal of Science, 43, 68-79 (In Vietnamese).

[9] Liu, C. W., Lin, K. H., and Kuo, Y. M. (2003). Application of factor analysis in the assessment of groundwater quality in a Blackfoot disease area in Taiwan, Science of the Total Environment 313, 77-89.

[10] Ly, N.H.T., and Giao, N.T (2018). Surface water quality in canals in An Giang province, Viet Nam, from 2009 to 2016. Journal of Vietnamese Environment, 10(2): 113-119.

[11] Mekong River Commission. (2015). Lower Mekong regional water quality monitoring report. ISSN: 1683-1489. MRC Technical Paper No.51.

[12] Ministry of Natural Resources and Environment. (2015). QCVN 08-MT: 2015/BTNMT National technical regulation on surface water quality.

[13] Ngoc, L.B. (2004). Assessing the environmental quality of intensive pangasius (Pangasianodon hypopthalmus) pond in Tan Loc commune, Thot Not district, Ho Chi Minh City Can Tho. Master's thesis in Environental Management, Can Tho University. (In Vietnamese).
[14] Nam, L.H., Hoai, D.T., Trang, N.T., Ngan, N.V.C. (2017). Surveying the status of the farming area and the quality of the water resources for Pangasius farming in Thanh Binh district, Dong Thap province. Science Journal of Thu Dau Mot University. S. 32 (2017), 181 - 190. (In Vietnamese).

[15] Nga, TN. (2009). Surveying surface water quality in the water body of Long Xuyen city (Ward area: My Binh, My Phuoc, My Long, My Xuyen) to determine the pollution level of the water area. An Giang University. (In Vietnamese).

[16] Ongley. E. D. (2009). Water Quality of the Lower Mekong River. In: Campell IC (ed) The Mekong: Biophysical environment of an international river basin. Acedemic, New York.

[17] Phu, T.Q, Ut, V.N. (2006). Water quality for pond aquaculture. Can Tho University. College of Aquaculture and Fisheries. 199 pp. (In Vietnamese).

[18] Thich, CV. (2008). Water quality and nutrient accumulation in intensive pangasius ponds (Pangasianodon hypophthalmus Sauvage, 1978) in Omon district, Can Tho city. Master's thesis specialized in fisheries. Can Tho University. (In Vietnamese)

[19] Truc, D.T., Phat, P.H., Nam, N.D.G., Toan, P.V., Tri, V.P.D. (2019). The water surface quality of Tien River in the area of Tan Chau district, An Giang province. Journal of Science Can Tho University. No 55(2019), 53-60. (In Vietnamese).

[20] Tuan, D.D.A., Thu, B.A., and Trung, N.H. (2019). Assessing quality of surface water for urban water supply source for Soc Trang City. Scientific Journal of Can Tho University, No 4A (2019):61-70 (In Vietnamese).

[21] Zeinalzadeh, K., and Rezaei, E. (2017). Determining spatial and temporal changes of surface water quality using principal component analysis. Journal of Hydrology: Regional Studies 13: $1-10$. 